\title{
UI'T'STAPJE NAAR HET BINNENLAND VAN NOORD-HALMAHERA
}

\author{
DOOR DEN \\ INSPECTEUR-HONORAIR UER CULTURES \\ J. E. TEYSMANN, \\ MET EEN WOORD TOT INLEIDING \\ DOOR \\ ROBIDE் VAN DER AA.
}

In 1872 bezorgde ik in dit tijdschrift de uitgave van twee bescheiden over Halmahera, die, hoezeer van oude dagteekening, nog geenszins verouderd zijn wegens de geringe kennis, die wij in onze dagen van dit hoofdeiland der eigenlijke Molukken bezitten. Het eerste, een Rapport over Tidoreesch-Halmahera dd. 20) October 1825 van J. P. C. Cambier, destijds voor een korte poos als Assistent Re:ident te Bitjoli gevestigd, is nog steeds de eenige volledige beschrijving der beide oostelijke schiereilanden; het tweede, de getrouwe afteekening eener in het begin der vorige eeuw voor Bewindhebbers der Compagnie vervaardigde kaart van het geheele eiland, is, vergeleken met onze nieuwste kaarten, een voor onze roeping als koloniale mogendheid beschamend gedenkstuk, daar er ten duidelijkste uit blijkt, hoeveel nauwkeuriger onze vaderen de tallooze bijzonderheden van Halmahera's wijd vertakte kustlijnen hadden opgenomen, dan wịj. Te dier gelegenheid gaf ik in een korte voorafsprak een beknopt overzicht van hetgeen onze eeuw aan de kennis van dit eiland had toegevoegd. Dit betrof bijna uitsluitend het noordelijke schiereiland en bestond vooreerst uit een belangrijk ethnologisch opstel van den kundigen Willer over de volksinstellingen der oorspronkelijke bewoners van Noord-Halmahera; voorts uit de reisaanteekeningen 
van een ongenoemde, die in 1852 de distrikten Sahoe, Djailolo, Kauw, Tabello en Galéla bezocht; eindelijk uit de waarnemingen der twee beroemde natuuronderzoekers Wallace en Bernstein. Van deze zoölogen bracht de eerste slechts een kort bezoek aan enkele der meest bekende plaatsen van Halmahera, terwijl de laatste, die op zijne beide reizen naar de Papoesche Eilanden ook eenige om de Baai van Weda gelegen kampongs van het zuidelịke en zuidoostelijke schiereiland in het voorbijvaren aandeed, zijn hoofdonderzoek bepaalde tot de oostkust van Noord-Halmahera en de daarvoor gelegen eilanden. Behalve hetgeen beide geleerden omtrent land en volk mededeelden, betroffen humne onderzoekingen uit den aard hunner studiën hoofdzakelijk de dierenwereld van dit eiland. Was dus Halmahera's flora tot dusver nagenoeg onbekend, des te belangrijker acht ik het, dat deze leemte thans eenigszins wordt aangevuld door de hieronder volgende reisopmerkingen van den heer Teysmann, die, in weerwil van zijn hoogen ouderdom, met rusteloozen ijver den Indischen Archipel in alle richtingen doorkruist, om het plantenrijk dier uitgestrekte eilandenwereld beter te doen kennen en den reeds terecht vermaarden Plantentuin van Buitenzorg aanhoudend met nieuwe gewassen te verrijken. 1

In de laatste helft van 1871 verzelde de heer Teysmann met dit doel den Gouvernements-Kommissaris van der Crab op een reis naar de West- en Noordkust van Nieuw-Guinea. Van dien tocht te Ternate teruggekeerd, gebruikte de onvermoeide reiziger het te dier plaatse noodige oponthoud, om de talrịke door hem in Nieuw-Guinea verzamelde planten en zaden te doen drogen, tot een uitstapje naar de oostkust van Noord-Halmahera, waar

1 De meeste vorslagen van $\mathrm{Teysmann}$ s botanische reizen zijn uitgegeven in het Natuurkundig Tijdschrift voor Nederl. Indië. Zon bevat D. XI zijne reis naar Oost-Java en Bali in 1854; D. XIV die naar Sumatra's Westkust in 1855 en 1856; D. XVIIl een tocht naar Banka en Palembang in 1857 ; D. XXIII het uitvoerig journaal zijner eerste reis naar de Molukken en Menado in 1860; D. XXV zijne bevindingen op een tocht naar Siam, werwaarts hij in 1862 een gezautschap onder den Algemeenen Sekretaris van Nelerlandsch Indië vergezelde; D. XXXIV het verslag eener reis naar Banka, Riouw en Linga in 1872 en het zeer uitgebreid dagboek der door hem een jaar later ondernomen reis naar Timor, de Allor-en SolorEilanden en naar het nog steeds zoo weinig gekende Flores en Soemba, terwijl men in D. XXXVI op nieuw zijne aanteekeningen op een tocht in 1875 naar Billiton, de Karimata-Eilanden en het door zijne goud- en diamantmijnen bekende Landak in West-Burneo aantreft. 
hị bij de daar sedert 1866 gevestigde zendelingen van het Utrechtsch Genootschap een gastvrij onderkomen mocht verwachten. De verslagen, die de heeren van der Crab en Teysmann van deze reis naar Nieuw-Guinea aan de Indische Regeering inleverden, werden met de journalen van twee latere reizen derwaarts van den heer Coorengel en van het stoomschip Soerabaja door het Departement van Koloniën aan het Instituut ter uitgave toevertrouwd, welks Bestuur mij met de vereerende taak belastte, daarvoor de noodige zorg te dragen en, waar ik dit noodig mocht achten, de mededeelingen dezer laatste Nederlandsche reizigers naar Nieuw-Guinea met die van vorige berichtgevers over deze uitgestrekte terra incognita te vergelịken. Terwijl deze journalen naar Nieuw-Guinea eerlang in een afzonderlijk boekwerk het licht zullen zien, achtte ik het wenschelijk, de beschrijving van Teysmanns tochtje naar Halmahera, die op zich zelf een eigenaardig geheel is, niet in dat groote, vrij omvangrijke werk optenemen, maar daaraan een afzonderlijk plaatsje in dit tijdschrift te gunnen. Juist was deze arbeid voor de pers gereed, toen ik kennis kreeg van de te Batavia uitgegeven Annales du jardin botanique de Buitenzorg, publiées par le Dr. R. H. C. C. Scheffer, Directeur de ce jardin, waarin reeds een uittreksel uit het journaal vau Teysmanns reis naar Nieuw-Guinea en van het daarin beschreven uitstapje naar Halmahera voorkomt. Bij vergelijking bleek mij spoedig, dat dit inderdaad slechts een uittreksel was, waarin met weglating der meeste , van Teysmanns geografische en ethnologische aanteekeningen, hoofdzakelijk alleen het botanische gedeelte is opgenomen. Er bestaat dus geen bezwaar, dezen arbeid alsnog het licht te doen zien, waarbij ik nu voor de juiste nomenclatuur der wetenschappelijke plantennamen de uitgave van den heer Schefler gevolgd heb.

Al is toch hetgeen de heer Teysmann over de plautenwereld van Halmahera mededeelt, door den gloed der nieuwheid het belangrijkste van dit opstel, niet minder trekt ons het schilderachtig tafereel, dat hij hier van het Meer van Galéla en de daar onder de onbeschafde Alfoeren gevestigde zendingposten schetst. Tot dusver was dienaangaande niets bekend, dan hetgeen uit brieven der zendelingen zelve is opgenomen in de Berigten der Utrechtsche Zendingsvereeniging, een tijdschrift, dat gewoonlijk alleen in handen komt van de voorstanders en ondersteuners dezer missie, maar ook de aandacht der weten- 
schappelijke wereld verdient, niet alleen om de mededeelingen over den nog zoo weinig gekenden heidenschen godsdienst dezer Aifoeren, maar ook uit een aardrijkskundig oogpunt. Als zoodanig wijs ik vooral op het nommer van Augustus 1877, waarin het verslag voorkomt eener reis, die de zendeling van Dijken in het begin van dat jaar langs de westkust van Halmahera deed, waarbij hij het eerst eene beschrijving geeft van het distrikt Lolodda, welks hoofd, hoezeer reeds sedert twee eeuwen aan den Sultan van Ternate onderworpen, nog steeds den alouden vorstelijken titel van Kolano voert, al moest hij, wat zijn gezag hetreft, de verklaring afleggen : "Mijn naam is wel Koning, "maar ik moet gehoorzamen", (t. a. pl. bl. 137). Ongetwijfeld is het van belang, nevens hetgeen de zendelingen over hum eigen werk berichten, nu ook eens over hun arbeidsveid het oordeel te veruemen van een onzijdig persoon als de heer Teysman, die, zooals men uit dit opstel zien zal, omtrent de door hen te verkrijgen resultaten alles behalve optimistische verwachtingen koestert.

Juist op dit oogenblik zullen mijns inziens nadere mededeelingen over Halmahera de belangstelling wekken, nu op dit eiland, dat sedert een halve eeuw geheel aan ons rechtstreeksch gezag onttrokken was, een belangrịke opstand is uitgebarsten, welks onderdrukking reeds tot grootere inmenging met het inlandsch bestuur aldaar geleid heeft. Danoe Hassan, de laatste afstammeing van den in het begin dezer eeuw in de annalen der Molukken zoo beruchten Radja Djailolo, is toch in het midden van 1876 eensklaps op Halmahera verschenen, om zich tot Sultan van dit eiland te verheffen, waar hij onder de voor het meerendeel met het despotisch wanbestuur der Sultans van Ternate en Tidor ontevreden bevolking weldra groote ondersteuning vond. Hoewel hij, zooals inen uit het Kolomiaal Verslag over 1877 en uit de laatste berichten der zendelingeu zien kan, voortdurend er naar streefie, om zoo met het Nederlandsch bestuur als met de evangeliepredikers op goeden voet te blijven, was onze regeering uit den aard der zaak verplicht, tot handhaving van het gezag harer leenvorsten dien opstand te onderdrukken. Sedert zijn dan ook op herhaalde expeditiën met de oorlogstoomers Pontianak en Banka de negorijen Weda en Maba, de hoofdzetels van den opstand, vernield en an de vloot van Damoe Hassan eerst in de tusschen Tabello en Gaíla gelegen Baai van Papilo, daarna in 
de tegenover Kauw liggende Bocht van Loelobato gevoelige nederlagen toegebracht. Daardoor werd de rust op de oostkust van Noord-Halmahera hersteld, zoodat de aanvankelijk gevluchte zendelingen, haudelaars, en Ternataansche ambtenaren reeds in den aanvang van 1877 derwaarts konden terugkeeren. In Maart hreld daarop de Resident van T'ernate te Galéla een groote vergadering met de Ternataansche en Alfoersche hoofden, waarbij de door de laatste op te brengen belastingen en heerediensten nauwkeurig bepaald zijn en elke inmenging van het Ternataansch bestuur met de Alfoersche volksinstellingen verboden is. Nog veel belangrijker zijn de na de indiening van het Koloniaal Verslag ontvangen mailberichten, van hetgeen in Juli en Augustus j!. op Halmahera voorviel. Daaruit weet men, dat Danoe Hassan, strijdens moe, zich aan de Nederlandsche regeering heeft overg geven en weder uit dit eiland verwijderd is. Sedert hebben de houfden der oproerige distrikten Maba en Patani alle den eed van trouw in handen van den Resident afgelegd, terwijl men weldra de geheele onderwerping mag te gemoet zien van het distrikt Weda, waar Danoe Hassan zijn laatste toevluchtsoord had bij een tot dusver geheel onbekend binnenmeer achter de negorị Kia (Koge in Melvills Atlas). Bleek het reeds uit het Kolon. Verslag, dat een kontroleur en twee posthouders met het toezicht der zaken van Halmahera zouden belast worden, thans vernemen wij, dat Nederlandsche ambtenaren met de noodige bezetting voorloopig te Galéla, Bitjoli en Patani gevestigd zijn, terwijl ook Gané, de hoofdnegorij van het onder Ternate behoorende Zuid-Halmahera, bezet zal worden. Evenals dit reeds in Maart voor Noord-Halmahera geschiedde, zijn thans in geheel Tidoreesch-Halmahera al de oude heffingen in produkten afgeschaft en door een vaste belasting in geld vervangen, terwịl de Sultan van Tidr met zijne rijksgrooten an den Resident heeft toegezegd, dat de slavernij in zijne onderhoorigheden op Halmahera en NieuwGuinea zal worden opgeheven. Van al deze mantregelen mag men verwachten, dat er thans een nienwe aera. aanbreekt voor het te lang door het Nederlandsch gezag verwaarloosde Halmahera, welk eiland onder het rechtstreeksch toezicht van Europeesche ambtenaren en door het dagelijkseh verkeer met de zendelingen na een niet al te lang tijdsverloop eene even schoone parel kan worden aan de kroon van Insulinde als de




punten van overeenkomst met de Alfoeren van Halmahera aanbiedt. Laten wị thans den heer Teysmann het woord.

's Hage, Maart 1878 .

R. A.

"Den 10den November 1871 vertrok ik des morgens om acht uur van Ternate met een korra-korra van den Sultan, bemand met elf roeiers, naar Dodinga, waar wij des namiddags om half vier aankwamen. De Rivier van Dodinga is nog een eind weegs bevaarbaar tot aan een kleine kampong van Ternatanen, die vlak an de rivier gelegen is; dit vaarwater is sedert 1860 aammerkelijk verbeterd, daar onze prauw nu bij hoogwater tot voor de kampong naderen kon, hetgeen destịjds alleen met kleine kano's langs een geul tusschen de rhizophoren kon geschieden. Evenals toen loopt de weg steil omhong naar een vervallen fortje, dat sedert eenigen tijd verlaten is en thans bewoond wordt door een posthouder met eenige oppassers. De kampong Dodinga, die daaraan grenst, is bijna geheel uitgestorven door de pokken, die daar vroeger geheerscht hebben ${ }^{1}$. Een vorig Resident heeft hier nast het fort een huisje laten bouwen voor tịdelijk verblijf bij zijne inspectie-reizen, waarvan ik gebruik mocht maken, om te overuachten. Het was den geheelen dag drukkend warm, doch des nachts werd het vrij koel.

Den 11den November, des morgens om zeven uur, wandelde ik over den Pas van Dodinga naar Babane, welken afstand men in een goed half uur kan afleggen 2 . De roeiers van Ternate waren angenomen, om de geheele reis mede te maken, zoodat zij een gedeelte mijner bagage medevoerden, terwiji het overige door koelies uit Dodinga gedragen werd; de hoofden der kampong waren mij daarbij zeer behulpzaam, hetgeen wei noodig was, want anders loopt het volk hier niet

1 De bezetting van Dodinga werd omstreeks 1868 ingetrokken, maar ten gevolge van den opstand van Danoe Hassan is daar in Dec. 1876 op nieuw een officier met 30 soldaten geplaatst. De hevige pokkenepitemie, van welker verwo stingen ook Bernstein gewag makt (Tijdschr. Bat. Gen. XIV, bl. 419), woedde in 1861.

R. A.

2 In de Molukiken beteekent pas geen overgang over een hergrug, maar de landstrook, die verschillende deelen van een eiland aan elkander verbindt, zooals bijvoorbeeld op Amboina de Pas van Bagoeala; deze uitdrukking is blijkbaar aan het P'ortuge esche of Spatusche passo ontieend. R. A. 
hard. De prauw van den Sultan liet ik te Dodinga achter, daar het distriktshoofd reeds een andere voor mij te Babane in gereedheid had laten brengen. Ware dit niet geschied dan had men de reeds gebruikte prauw over den pas moeten sleepen; nu kon ik mij reeds om half negen te Babane inschepen, om terstond de reis voort te zetten. Daar de wind ongunstig was, moest er aanhoudend geroeid worden en de roeiers, die door hun hoofd, den kapala-prauw, slecht werden aangespoord, maakten geen groote haast, zoodat wij niet voor tien uur des avonds te Kauw aankwamen. Wegens het bezwaar, om in dit late uur te landen, bleef ik maar in de prauw overnachten. Aan koken op dit vaartuig viel niet te denken, doch ik had gekookte rijst van Dodinga medegenomen, waarmede ik reeds mijn middagmaal gedaan had; nu gebruikte ik die ook aan den avonddisch, dien ik verder met een blikje hazenpeper aanvulde.

De oostkust van Halmahera, die wij heden volgden, liep van het gebergte tot in zee steil af en was geheel met woud bedekt. Sporen van menschen of landbouw waren er niet; slechts cene enkele woning met eenige klapperboomen kregen wij tegen den avond te zieu. In de nabijheid van Kauw 1 trok het gebergte zich meer terug en werd het land langs de kust lager; zoo zelfs, dat er sago-bosschen voorkwamen, die men alleen in merassige streken aantreft. De stank op de laatste prauw was in den aanvang afschuwelijk, waarom ik dacht, dat men trassi aan boord had medegenomen. Bij onderzoek werd daarvan echter niets gevonden en het bleek nader, dat dit een gevolg was van het uitlooien der nieuwe prauw in het zeewater; de stank verminderde dan ook langzamerhand.

Deu 12den November ging ik 'smorgens aan wal, om koffie te drinken en rijst voor middag- en avondmaal te laten koken; voor ontbijt gebruikte ik steeds droge beschuit. Kauw is een groote kampong en er wonen zelfs Chineezen, die handel met de Alfoeren drijven; zij koopen hier rijst, sago, gedroogde visch, karet-schildpad en tripang en verkoopen lijnwaad en snuis-

1 Gewonnlijk wordt dit distrikt hane genoemd. De uitspraak Kauw is waarschijnlijk juister, daar dit oord reeds op de oude door het Instituut nitgegeven kaart van Halmahera en in andere stukken uit den tijd der Compagnie steeds Cau of Cauw genoemd wordt, welke schrịfwijze ook bij de het meest met de taal der inboorlingen vertrouwde zendelin;en in gebruik is.

R A.

4e Volgr. I. 
terijen. langs het strand vindt men een lange reeks van klapperboomen, waartusschen hier en daar, ver van de eigenlijke kampoug, nog huizen gemien worden

Om acht uur werd de reis naar Tabello voortgezet. Gedurende de vaart zagen wij bij afwisseling een zandig strand of rotsen, die tot in zee afdaslden; de huizen staan hier en elders alle op den vasten wal, niet ver van de zee, doch zijn niet op palen gebouwd, daar de aardbodem tot vloer strekt. Om half twaalf passeerden wị Poeloe-Bale; Tandjong Bian Medèhé ligt tegenover dit eiland 1 . Hier kregen wij een weinig wind, om te zeilen; bij tusschempoozen inoest er echter geroeid worden tot Tandjong-Miti en het daartegen over liggend eiland van dien naam. De geheele kust van Tandjong Bian tot Tandjong Miti 2 is wei niet hoog, doch het lage gebergte loopt steil in zee af en de kust is geheel onbewond. De eigenaardige vorm van het eiland Halmahera, wordt nog zonderlinger, wanneer men behalve de vier groote schiereilanden ook de vele uitstekende kapen met de daarvonr liggende eilandjes en de diep in het land indringende baaien in aanmerking neemt. Des avonds om acht uur kwamen wij voor Tabello aan, doch dewijl het zeer donker was en het landen moeielijk viel, getroostte ik mij, weder in de prauw te overnachten. Vroeger was hier een lange brug, waar men aan het hoofd kon aanleggen; doch hoe fraai die brug of steiger eenmaal moge geweest zijn, thans was zij geheel onbruikbaar.

Den volgenden morgen ging ik aan wal en ontmoette den zendeling Been met zijne echtgenoote. Hij heeft hier een lief huisje opgericht en is kraak zindelijk ingericht, hetgeen nog al eenig verschil oplevert met de vuile woningen der Alfoeren. Het terrein om zijn huis is goed schoongehouden, met bloemen en vruchtboomen beplant en omheind tegen het indringen van geiten; de heesterachtige katoen tiert hier zeer welig. Arbeiders zijn hier tegen f. 6 's maands genoegzaam te bekomen, hetgeen elders niet het geval is. Dit erf is een model voor de Alfoeren, maar het goede voorbeeld van den zendeling vindt

1 Bij Bernstein heet deze kaap Tandjong Patjikara en het daarvoor liggend eilandje Bobale, (Tijdschr. Bat. Gen. XIV, bl. 420). Ook in het Tijdschr. van N.-Indië voor 18.56, D. II, bl. 227, heet dit eiland Babale, op de kaart in Petermanns Mittheil. voor 1873 Balili. R. A.

2 Deze kaap heet bij Bernstein (t. a. p. bl. 422) T'andjong Mamséa. R. $\Lambda$. 
bij hen nog weinig navolging. Zelfs heeft de heer Been hen nog niet zoo ver kumnen brengen, dat zij den weg en humne erven in de kampong schoon maken; alles is er met gras en struiken begroeid. Er is hier evenals te Kauw een zoogenaand residentie-huis, dat door den Djoegoegoe bewoond wordt en er even vuil en verwaarloosd uitziet, als hot overige. Hier wonen meest Orang Slam, die niet beschaufder dan de Alfoeren en meestal nog werkelijke Heidenen zijn; ook heeft zich hier een Chinees gevestigd. De Alfoeren in de verschillende distrikten van Halmahera sprekeu evenals de bewoners van Nieuw Guinea, Ceram, Celebes, Boeroe en Borneo, verschillende talen en dialekten 1. Ook staan zij soms vijandig tegenover elkander; het gezag van den Sultan van Teruate makt de twisten hier echter minder bloedig dan elders.

Oı 8 uur 'smorgens vervolgde ik de reis naar Galéla, nadat ik bij den heer Been koffie gedronken en rijst voor de vaart gekookt had. Het land langs dit deel der kust is laag; het schijnt zeer vruchtbaar en is gedeeltelijk door Alfoeron bewoond, hoewel aan het strand geen kampongs te zien zijn. Meer bimenwarts steeg nu en dan rook op; de Alfoeren houden zich toch niet alleen aan de kust op, maar wonen ook ver in het binnenland. Het strand is hier en daar zandig, verderop ook met zwarte rotsblokken bedekt, die meer en meer toenemen, hoe meer men Galéla en den voet van den Goenoeng Mamoeja nadert, totdat eindelijk de kust voorbij 'Taudjong Lari 2 in een geheel zwarte vulkanische massa overgat, de zoogenoemde Batoe Angoes 3. De Goenoeng Mamoeja, die $t 3000$ voet hoog zal zijn, daalt met verscheiden ribben in zee af, waarvan 'Tandjong Lari de uiterste punt untmaakt. Zoodra men deze laatste kaap omzeild heeft, valt het oog zoowel op

1 Men zie over de talen van Halmahera en de nabijgelegen eilanden, waaronder die van Noord-Halmahera eene zoo eigenaardige plaats bekleeden, mijn opstel in de Bijdragen van dit Instituut, R. 2, D. VII, bl. 267. Overigens blijkt uit het bovenstaande, dat de heer Teysmann onder het woord Alfoer geen bepaald ras, maar eenvoudig den nog niet tot den Islam bekeerden inl Inder verstaat; zie mijne aanterkening hierover in von Rosenberg, Reistochten naar de Geelvinkbaai, bl. J't.

R. A.

2 Tandjong Loeari bij Bernstein (t. a. p. bl. 407 en 412). R. A.

3 Ook op Ternate heeft men den Verbuanden Hoek of Batoe Angoes van batoe steen en angoes, brand. R. $A$. 
den zonderling aforknotten here Kerkan 1 nabij Gałéla, als op de uitgestrekte Batoe Angoes, die zoo hoog, als de golven reiken, zwart en zonder vegetatie, doch datarboven met een groen plantenkleed bedekt is. Onwillekeurig rijst onmiddelijk het denkbeeld op, dat deze vulkanische stroom afkomstig is van den wel voor twee derden ontbrekenden top van den Kerkau; bij nader onderzoek bleek het echter, dat dit niet het geval kon zịnn.

Omstreeks elf uur kregen wị een fiksche regenbui, en tegen drie uur des namiddags landden wịj te Galéla, waar ik mịn intrek nam in de ook hier bestaande residentswoning, waarin de Oetoesan van Ternate zijn verblijf hield, die terstond een kamer voor mij inruimde. Het was hier even vuil en haveloos als elders, doch ik was reeds tevreden, dat $\mathrm{k}$ onder dak was en dat ik de gelegenheid had, water en rịjst te laten koken; de laatste had ik zelf medegebracht met al de verder benoodigde gereedschappen en provisiën. Niet lang geleden had hier een zeer zware storm gewoed, die de zee tot over den hoogen oever had opgevoerd en waarbij vele prauwen, doch geen menschen verongelukt waren.

Den 14den November wandelde ik des morgens door de kampong, die er beter nitzag dan Tabello, en verder langs het strand tot aan de Batoe Angoes, waar ik door een moeras gestuit werd. Ik nam daar een prawwje, om langs het strand en de inhammen op de vulkanische massa te botanizeeren, en het gelukte mij, er verscheidene merkwaardige planten te vinden en te verzamelen. Dit varen was evenmin gemakkelijk, als het gaan over de scherpe lava, daar de zee meest tot aan de rotsen met koraal-banken bezet is. In een dezer inhammen besteeg ik een gedeelte der rotsmassa, waar een droge waterloop een altiid nog steenachtig voetpad vormde. Onder een groote verscheidenheid van planten, heesters en zelfs vrij groote

1 Wegens den eigenaardigen vorm heet deze berg op de oude Compagnie-katart Tafelherg. De naam Goenoeng Tarakan bij Bernstein (bl. 408 en 409) is hoogst waarschijnlijk juister, daar de zenilelingen dien ook bezigen en volgens eene oude legende den oorsprong dier benaming uit het Ternataansche tarakan (stok) verlilaren, zie Berichten Utr. Zending, 1877, bl. 128. Misschien heett de heer Teysmann den vorm liekan nit het Karakan van Melvill's Atlas ontleend, terwijl een soortgelijke diukfout in het Tijdschr. van Neerl. Indië (t. a. p. bl. 222, dezen berg in Serkanoe heriloopt. R. A. 
boomen komen hier voormamelijk voor: de Pandanus spurius, Pandanus latissimus, Cycas Rumphii, Fagraea euneura, Sterculia Halmaherae, Aegiceras, Xylocarpus, Rhizophora, Bruguiera cylindrica, Ceriops, Kandelia Rheedii en Cyperaceae. Het is verwonderlik, dat op dezen rotsbodem, waar vau humus of verweering nog weinig sprake is, zelfs groote boomen zich door aauhechting tusschen de rotsen indringen en zich dus het noodige voedsel weten te verschaffen. Hoe verder men landwaarts over die uitgestrekte vulkanische massa heen ziet, hoe weelderiger de plantengroei wordt, terwijl die nader bij het strand langzamerhand afueemt; het is echter niet mogelijk, dat men zich over de uitstekende, ouregelmatig daar neergeworpen rotsen een weg baant.

Deze uitbarsting moet reeds in lang vervlogen tijden hebben plaats gehad; men wist mij slechts bij overlevering, eenig bescheid daaromtrent te geven, waarbij echter alweder verschillende leziugen voorkwamen. Het waarschijnlijkste kwam mij voor, dat de meer in het bimmenland gelegen Goenoeng Tolo 1 deze vulkanische massa heeft uitgeworpen, die rich palen ver uitstrekt en tusschen de bergen Maıoeja en Kerkan besloten is. Weilicht was toen de plaats, welke thans met die massa is angevuld en opgehoogd, een baai of inham der zee, warin de lava zich gemakkelijk kon voortbewegen. Dat deze vulkanische stroom niet van den Goenoeng Kerkan kan uitgegaan ziju, blijkt dan ook ten duidelijkste, dewijl de stroom niet van die zijde, maar uit het westen of zuidwesten gekomen is, en er geen sporen van uitbarstingen van den kerkan, noch een weg, welken die stroom zou moeten gevolgd hebben, te zien zijn. Looals mij later bleek, heeft deze berg twee derden zijner oorspronkelijke hoogte door verzakking verloren, op weike wijze ook de bimmenslands gelegen meren moeten ontstaan zijn. De zwarte rotsklompen, weike

1 Reeds Valentijn vermeldt (D. I. B. bl. 95), zonder echter een bepaald tijustip op te geven, de voorheen zon geweldige uitbarstingen van den berg Tolo, welken hij echter verkeerdelijk van Halmahera's noordoostkust, het bij de oude Spaansche en Portugeesche schrijvers zoo herhaaldelijk vorkomende Moro, naar het tegenoverliggende riland Morotai verplaatst. Volgens eene door de Utrechtsche zendelingen medegedeelde legende (Ber. 1877, bl. 130), was Tollo of Tolo de oude naam van het district Gaiéla; deze plaats, het San Juan de Toio der Spanjaarden, werd geheel door zulk een uitbarsting bedolven en verkreeg eerst na hare herbouwing den tegenwoordigen naam Galéla. R. A. 
men langs het strand van den voet van den Goenoeng Mamoeja tot aan de Batoe Angoes aantreft, schijnen eveneens tot deze uitbarsting te behooren en door de zee derwaarts gevoerd te zijn. Aan den voet van den Mamoeja moet zich ook een warme bron bevinden nabij een kampong van denzelfden naam. 1

Het strand van Galéla bestaat van de Batoe Angoes af uit mul zwart zand, dat vele voeten hoog ligt. Daarop en daarachter is de kampong gelegen, warin zoowel Alfoeren, als Mahomedanen en Chineezen gevestigd zijn; van de laatsten minstens een dozijn, die van den handel leven. Sago wordt er door de Alfoeren veel angevoerd en voorts de reeds onder Tabello vermelde waren. De Alfoeren onderscheiden zich hier weinig van de Mahomedanen, behalve dat zij slechts met de tjidako gekleed zijn. Bij feestelijke gelegenheden komen zij echter in hetzelfde kostuum als deze hunne dorpgenonten voor den dag en dragen dan zelfs hoofddoeken; geen van beiden laten het haar lang groeien. De Alfoersche vrouwen dragen onder gewone omstandigheden korte kleedjes, maar zijn bij feesten even fraai uitgedost als de Orang Slam; zij hebben ook evenals deze schoon, lang en zwart haar. Men vindt hier geen bronwater, maar wel vele gegraven putten, wier water, dat ook gedronken wordt, zoo vuil is, dat men het noode tot baden bezigt.

Voor vijf jaren vestigden de zendelingen zich te Gaiéla, doch nadat hunne huizen door onvoorzichtigheid in brand geraakt en geheel afgehrand waren, verhuisden zị naar Tabelio en naar het zoetwateruneer Talaga-lamo, dat is Groot Meer, hetgeen een half uur gaans van de kampong Cialéla in het binnenland ligt. Dan moet men nog bijna een half uur varen, om aan de woning van den zendeling Klaassen te komen, die bij de kampong Swakenora ligt; daar swake of soewake, ook doko, kampong en no ra midden beteekent, kan die naam door Middeldorp vertaald worden. Daartegenover, op korten afstand van het meer, woont een ander zendeling, de heer van Dijken, niet ver van de kampong Dokolamo, dat is Groote Kampong, op zijn heerlijk buitenverblijf, waaraan hij den bijbelschen naam Duma schonk.

1 Bernstein, die uit de kampong Mamoeja zoowel dien berg als den Tolo besteeg, vermelit deze warme bron niet; het opstel in het Tijdschr. voor Ned.-Indië, bl. 222, verzekert echter, dat er bij deze negorij eene warne rivier Ake sahoe is.

R. A. 
Aan die heeren verzocht $i k$, een paar dagen bij heu te mogeu doorbrengen, hetgeen mij gereedelijk werd toegestaan, Ik begaf mij daarop den 15 den November op reis, langs een vroeger goed aangelegd, doch thans bijna dicht gegroeid voetpad, dat nu eens klom en dan weder daalde. Te Babane, waar eene steile helling naar het meer afdaalt, stapte $i \mathrm{k}$ in een prauw en kwam daarmede spoedig bị den heer Klaassen aan, die mij evenals zijne echtgenoote hartelijk weikom heette. $\mathrm{Zij}$ bewoonden een klein, doch lief huisje, eerst kort geleden voor hen opgericht; een ruim erf omringt bet, want aan grouden is hier nergens gebrek. Het is hoog boven, doch dicht aan het meer gelegen, terwijl in de onmiddelijke nabijheid eenige Alfoersche huizen staan, die tot de kampong Swakenora behooren. Men geniet van daar een heerlijk uitzicht, zoo op het meer als op de groene oevers en een paar kleine eilandjes, die eveneens met groen bewassen zijn, terwijl de berg Kerkan, die met zijn voet tot aan het meer reikt en aan deze zijde nog geheel met bosch bedekt is, den achtergrond vormt. Een paar soorten vau wilde eenden zwemmen in dit meer rond, dat echter ook krukodil!en bevat, die soms de eenden en ganzen weg rooven. Het klimaat is hier veel frisscher en de nachten zijn koeler dan aan het strand te Galéla.

Het meer is volgens de zendelingen 26 vademen diep, drie kwartier roeiens lang en bij ongelijke breedte | 20 minuten breed; het beslaat een onregelmatig langwerpig vierkant. Er leven bijna geen visschen in; slechts zeer kleine vischjes, als stekelbaarsjes, en een soort van ikan lélé of gaboes, waren de eenige, die men kende. Als een gevolg dezer schaarschlieid van visch ziet men hier zelden watervogels 1, terwijl wegens de diepte van het meer daarin geen waterplanten groeien, behalve op sommige plaatsen langs de kanten. Nelumbium speciosum is er nog al vertegenwoordigd, doch komt zelden in bloei, daar de bloemstengel zich niet boven het water verheffen kan en de bladeren ook zelden opstaan, maar meest altijd op de oppervlakte van het water drijuen. Eene Potamogeton en eene Utricularia ziet men ook veel op ondiepe plaatsen langs den oever. Het water is goed vau smaak en wordt alge!neen als drinkwater gebruikt, hoewel

1 Het lag waarschijnlijk aan het jaargetijde, dat de schrijver zoo weinig watervogeis aan dit meer opmerkte, terwijl Bernstein er in Juh en Augustus zoo veel aantrof (t. a. pl. bl. 409.)

R. A. 
de zendelingen putten hebben laten graven, omdat het meerwater wel eens door de inboorlingen verontreinigd wordt; het meer heeft wegens de diepte een donkere kleur, als men er over vaart. Bij het graven der put te Swakenora werden eenige nieuwe Hollandsche rijksdaalders in een graf' gevonden, welke de inlanders zich niet durfden toeëigenen, daar zij beweerden, dat die den daar begravene toebehoorden. Behalve de zoo evengenoemde eilandjes, die men van de woning van den heer Klaassen zien kan, zijn er nog vele andere over het meer verspreid, waarvan sommige met humue rotswanden hoog boven het water uitsteken.

Langs het meer, hoewel niet zichthaar aan den oever, en verder in het binnenland, zijn vele Alfoersche kampongs 1, wier huizen alle achtkant zijn en daardoor een zonderling aanzien hebben, wel iets gelijkende naar een eenden- of kippenhok. Die vorm wordt echter gemakkelijk verkregen door het afkappen der uiteinden van de galerijen, warbij het middengedeelte der woning vierkant blijft. Zij staan niet op palen, maar vlak op den grond, doch men vindt er verheven slaapplatsen en zelfs honten zithanken in.

Evenals elders werken deze Aifoeren liefst niet meer dan hoogst noodzakelijk is. Hunne cijnsbaarheid aan den Sultan van 'Termate noopt hen evenwel, om padi te planten, waarmede zij hunne landrente kunnen betalen, door een gedeelte te verkoopen 2, terwijl zị zelve, bij afwisseling met sago, ook gaame rijst eten. Tabak telen zij op hunne ladangs tegelijk met en in de nabijheid der padi; de planten, die ik er van zag, waren klein van blad, doch overigens vrij goed. Ook de

1 Het opstel in het Tijdschr. van Neerl. Indie, bl. 222, noemt behalve Soeakenora en Dokolaino de volgende zeven negorijen aan dit meer: Soeagira, Togawa, Mamoeja, Ṡgo Boelon, Bali, Tobaro en Nadiko. In de Berichten der Utrechtsche Zendingsvereeniging, jaargang 1869, vindt men een uitvoerig schetskaartje van het meer; daaruit ziet men, dat de lengteas van het oosten naar het westen loopt. In die richting vindt men laugs den noordoever de kampongs: Tabaroe of Tauana, Ngidihoe, Bora en Dokkolamo, anu het westeinde Tabaroe en verder langs de zuidkust: Sabali, Ari, Bali of Belo, Igoe of Makoe-Boela, eindelijk Soakonora, het dichtst bij den weg naar Galéla.

R. A.

2 Hieruit zou men opmaken, dat de schatting aan den Sultan van Teruate in geld voldaan wordt, terwijl volgens Willer, Het eiland Boeroe, bl. 60 het distrikt Galéla rijst in natura, en wel zes kleme gantangs per huivgezin, opbracht.

R. A.

Downloaded from Brill.comø4/26/2023 01:56:34PM via free access 
padi had een goed voorkomen en kan met die der ladangs op Banka vergeleken worden; zij was kort van gewas, doch goed geladen. Damar wordt in de bosschen verzameld, zoo voor eigen gebruik om te branden, als voor den handel.

De inwoners leven rustig onder elkander, doch zijn zeer geneigd, ten oorlog te trekken, vooral met het doel, om buit te maken en ook voor de eer, om voor heldhaftig gehouden te worden, daar zij na den veldtocht hunne zegeteekenen in de tempels ophangen. Het kost den Sultan daardoor weinig moeite, wanneer dit door het Gouvernement verlangd wordt, honderden Alfoeren te vinden, gezind, om ten strijde te trekken. Evenzeer uit verveling, omdat zij hun tijd niet weten te besteden, zwerven de jongelieden soms jaren lang op goed fortuin rond. Dat zich onder die omstandigheden wel eens een zeeroover vormt, is meermalen gebleken, maar veelal keeren zij na eene afwezigheid van tien of twintig jaar naar humne betrekkingen terug. De zendelingen wonen echter rustig en vreedzaam onder deze Alfoeren, zonder het minste gevaar voor hun leven of voor hume bezittingen.

Aan bijgeloovigheden ontbreekt het bij deze lieden evenmin als bij andere volkeren. Voor hunne dooden hebben zij meer achting, dan voor de leveuden en de ouden van dagen. Na het overlijden wordt aan de lijken de meest mogelijke eer bewezen en men spaart dan geen kosten, om den geest van den overledene te bevredigen. Er komt daarbij evenwel eigenbat in het spel, daar zij voor de zielen of geesten der overledenen, die steeds in humne nabijheid zweven en al hun doen en laten gadeslaan, groote vrecs koesteren en zich dus met hen trachten te verzoenen. $\mathrm{Zij}$ zullen daarom nooit een gelofte breken, omdat de geesten hun dit zeer kwalijk zouden nemen en hun ongeluk zouden berokkenen. Vele snuisterijen en zaken van dagelijksche behoeften, zelfs zilvergeld van aanzienlijke waarde, worden met de dooden ter aarde besteld of op de graven neergelegd. Het porselein of aardewerk, zooals kopjes, schoteltjes en borden, dat men op die graven vindt, is echter, evenals bij de Sekì's op Banka, altijd gebroken of beschadigd; het doel daarvan is mij niet geb?eken.

De begrafenis geschiedt in de verschillende distrikten niet op dezelfde wijze. Te Galéla begraaft men de lijken in de aarde, doch delft die later op, om het dan nog overgebleven gebeente te verzameien en in een klein fraai kistje op palen 
van drie a vier voet hoogte boven het graf te plaatsen. Te 'Tabello daarentegen begraaft men de lyjken niet, maar legt die, goed ing wikkeld en met matten (tikars) omwonden, in een open kist op palen van de hiervoor vermelde hoogte en wacht dan de ontbinding van het lijk af, om daarma, evenals boven gezegd is, de beenderen te verzamelen en in eeu klein open kistje weder ter plaatse op te stellen. Het vreemdste der zaak is, dat in beide distrikten deze graven dicht bị de kampongs liggen, zoodat zij soms geen vijf en twintig pas van de woningen verwijderd zijn; dit kan niet nalaten, een verpestenden stank te verspreiden, waarvoor de reukorganen dezer lieden echter minder vatbaar schijnen te zijn.

De Alfoeren gelooven aan een betere en genotrijke toekomst na den dood. De straffen van het vagevuur, de hel of van soortgelijken aard zijn bij hen niet bekend, en huune booze geesten (Setan, A ntoe, Swangi en dergelijken) maken het hun alleen in dit leven soms wat lastig. Hume beschermheiligen kiezen zij naar welgevallen, meest een slaug of ander gedrochlịk wezen, wier houten beelden zij in hume tempels (s a bo e a) ophaugen, waarin ook de zegeteekenen: in den strijd veroverd, bewaard worden. Zulke krijgstochten worden ook aangeduid door de jonge gele bladeren van den aren-boom (Gotta Madolo), die aan de daklatten worden vastgeknoopt. Hume saboea's zijn min of meer groote gebouwen, die niet bewoond worden, maar behalve tot bovenstaande doeleinden ook tot feestelijke of godsdienstige samenkomsten dienen; zij zijn niet onwand, maar soms van zitplaatsen voorzien en vertegenwoordigen de missigits der Mahomedanen en de kerken der Christenen. Veel nog zoude van de gewoonten en bijgeloovigheden dezer Alfoeren te verhaten ziju; ik heb daarom de zendelingen aangespoord, dairvan al het hun bekende te boek te stellen en door deu druk meer algemeen bekeud te maken 1.

Den 16den November bracht ik met mijn gastheer per prauw over het meer een bezoek aan den heer vau D!jken en zijne echtgenoote te Duma, die daar een aardig huis met bloementuin heeft aangelegd. Koflie en arrowroot zijn ook door

- In de Berichten der Utrechtsche Zendingsvereeniging vindt men reeds verschillende belangrijke bijzonderhe ten over de godsdienstige voorstellingen en eeredienst dezer heidensche Alfoeren. Weuschelijk blijft het mettemin, dat de zundelingen daarwan een systematisch beweıkt overzicht in het licht geven.

R. $A$. 
hem aangeplant, van welk laatste produkt hij reeds veel naar Nederland aan het genootschap te Utrecht gezonden heeft. De bodem is er zeer vruchtbaar, waar katoenheester en wijilstok welig tieren; ongelukkig konden de zendelingen de laatste plant niet behoorlijk behandelen. De heer van Dijken bezat bovendien zeven vette koeien van Bengaalsch ras, die er prachtig en welgevoed uitzagen; er is hier dan ook geen gebrek aan voeder, want tusschen Duma en de kampong Dokolamo ligt een uitgestrekt en vlak terrein, geheel met ḱoesoekoesoe of allang-allang bedekt, waarop wel een honderdtal runderen ruim voedsel kan vinden. Het transport van vee naar Ternate, de eenige markt er voor, is echter bezwarend, daar het prauw-loon voor enkele beesten te duur zou uitkomen en het vervoer daarbij nog imet veel moeite zou gepaard gaan.

Van Swakenora naar Duma hebben de zendelingen voor humne rekening een goed voetpad aangelegd, dat op geringen afstand van het meer oenige kaupongs doorsnijdt. Zij hoopten, dat de A!foeren dit voorbeeld zouden volgen en dat het maken van goede wegen een begin van beschaving zal ten gevolge hebben. Er bestond ook plan, dezen weg van Swakenora tot Galéla door te trekken, waarvan trouwens een groot gedeelte, dat van Galéla tot Babane, reeds bestaat. IIet woord babane is, zoo hier als op den landtong van Dodinga, ontleend aan de steile hellingen, die er gevonten worden.

Met den heer van Dijken makte ik een flinke wandeling langs den nieuw aangelegden weg en door de kampongs, die bijna alle verlaten waren, daar de bewoners zich wegens den padi-oogst op hunne ladangs gevestigd hadden. De kampongs waren vrij goed onderhouden en prijkten alle met de graven en beenderenkistjes der dooden op palen in de onmiddelijke nabijheid der woningen. Vruchtboomen, voornamelijk manga's en doekoe's, werden overal aangetroffen, maar mangies of mangostans waren er schaarsch. De kembang. spatoe (Hibiscus Rosa Sinensis), de granaatappel (Punica Granatum, de melati-gambier (Jasminum grandiflorum) en de melatibetoel (Jasminum Sambac) ontbraken nergens. Des avonds keerden wij per prauw naar Swakenora terug; het water in het meer was toen door den wind zeer bewogen, zoodat wij gedurig kleine golfjes in onzen notendop binnen kregen, die er met een klapperschil weder uitgeschept werden.

Daar ik vernomen had, dat er behalve het groote meer 
Talaga-lamo noordwaarts nog drie andere meren bestonden, wenschte ik ook die te bezoeken, waarbij de heer Klaasseu mij zoude vergezellen. Wij stapten dus den 17 den November weder in een prauw, voeren het meer over, worstelden met veel moeite door een veld van dicht in elkander gesloten, op het water drijvende bladereu van Taratte (Nelumbium speciosum) en bereikten eindelijk den oever, dien wị beklommen. Wij vonden op de hoogte vele ledige huizen, maar eindelijk ook een bewoond huis, welks bewoners ons terecht wezen, zoodat wịj, aan de andere zijde wweder afdaiende, het tweede meer bereikten. Dit meer besloeg veel minder oppervlakte, misschien nog geen vierde van het groote meer; ook was hier niets bijzonders te zien. Wij wilden daarna de twee nog noordelijker gelegen meren bezoeken, doch daartoe bestond van hieruit geene gelegenheid en wij zouden daarvoor een grooten omweg hebben moeteu maken; de tijd veroorloofde ous dit niet, zoodat wij maar besluten terug te keeren. Van de twee andere meren verhaalde men ons, dat het eene klein, maar dat het verste groot en lang was; dit laatste zou langs den voet van een in het verschiet zich voordoenden bergrug loopen en zich zeewaarts wenden, doch van geen van alle was een uitwatering bekend. Het ontstaan dezer meren is, in verband met het verdwijnen van deu top van den Kerkan, waarschinlijk aan verzakking van den hodem toe te schrijuen 1.

$\mathrm{Na}$ een hartelijk afscheid van de brave zendelingen keerde ik des avouds naar Galéla terug. De poging van het Utrechtsche Genootschap, deze lieden hier midden onder de echte $\Lambda$ lfoeren te plaatsen, is schoon, doch getuigt niet van zaakkenuis, daar men hier er evenmin in slagen zal, Christenen te maken, als in Nieuw-Guinea. Vooreerst zijn de inwoners zoo bijgeloovig aan hunne oude overleveringen gehecht, dat zij daarvan niet durven afwijken uit vrees voor de schimmen hunner voorouders; ten tweede gevoelen zij geene behoefte naar verandering van godsvereering; ten derde is de Christelijke leer; zooals die door de zendelingen gepredikt wordt, hun ten eenenmale onbegrijpelijk. Daarbij koint nog, dat zij alleen om bijzondere redenen tot den godsdienst van humnen vorst, den Islam, overgaan, hoewel die voor hen veel aannemelijker is dan het Christendom. Scholen voor de jeugd zouden nog het wenschelijkste zijn,

1 Ook Bernstein, die allcen het groote meer of Meer van Galelı bezocht, verklaart dit uitdrukkelijk (bl, fo9) voor een frezonken krater: $\mathrm{F}$. A. 
doch de kinderen, die van de ouders geen aansporing te wachten hebben, vinden het veel a angenamer, zich in het water of in het zand rond te wentelen en zich in de zon te bratien, dan op school te gaan; daarvan waren ten minste tot dusver geen resultaten verkregen 1 .

Met den heer van Dijken had ik afgesproken, dat wij den 18 den November den Goenoeng Kerkan zouden beklimmen, om diens zonderlingen vorm vau nabij te beschouwen. Onze weg lag aan de oostzijde des bergs en liep eerst door allang-allang-velden, doch weldra onafgebroken door het woud. De hoogte van dezen berg schatten wij op niet veel meer dan 1000 voet boven de zee ${ }^{2}$; wij beklommen die, langzaam voortgaande, daar het nog al steil in een rechte lijn opwarts ging, in anderhalf uur, terwijl wij slechts een half uur behoefden, om -nel af te dalen. Boven gekomen, zagen wij een effen terrein, dat als een ring rondom den top des bergs liep en nu eens zeer smal, dan weder eenige roeden breed was. Hel bimnenste van dien ring liep even steil naar beneden, als de buitenwand des bergs, zoodat het binnengedeelte, waar de top moet gestaan hebben, nu in een grooten trechter herschapen is, die echter op de hellingen even als de buitenkant met bosch bezet is, waardoor de bodem, wellicht een paar honderd voet diep, geheel onzichthaar was. Een onzer volgelingen daalde in den trechter tot den bodem af en kwam an de overzijde weder te voorschijn; hị wist ons niets anders te verhalen, dan dat er op den bodem geen water stond, mar dat die evenals de wanden met groote boomen, struikgewas en bamboe begroeid was. Het regenwater moet dus langs een onderaardsch kanaal wegvloeien, waarschijnlijk in het daaraan grenzende meer Talaga-lamo. Wij lieten onze geringe bagage ter plaatse, waar wij het eerst het

1 Naar al wat ons van de Alfoeren in Halmahera wordt medegedeeld, hebben zij veel meer overeenkoinst m.t de orspronkelyke bevolkmg van Noori-Celebes dan met de Papoes van Nieuw-Guinea. Waarom met der tijd do zending in Noord-Halinahera niet even goed zou slagen, als die der Minahassa, is ons niet duidelijk. Bij zulke ongunstige oordeelvellingen over den zendugarbeid bedenke men wel, dat de vruchten daarvan in den regel slechts langzaam rijpen. De latere herichten der zendelingen wa het bezoek van den heer $\mathrm{T}$ eysman $\mathrm{n}$ gewagen reeds van merkelijken vooruitgang, totdat de over het geheele eiland uitgebroken op-tand ook op het gebied der zending een tijdelijken stilstand te weeg bracht.

R. $A$.

2 Volgens waarneming van Bernstein met den barometer bedıagt deze hoogte 900 l'arijsche voeten (bl. 408). 
hoogste punt bereikt hadden, hingen onze door den regen nat geworden kleederen in de zon te drogen eu begonnen toen de wandeling op den ring rondom den grooten trechter. Mrest overal vonden wij zwaar bosch, doch ook allang-allang-velden, ontstaan door het vellen van het bosch, om daarop landbouw uit te oefenen. Deze ring was, zooals reeds gemeld is, van ongelijke breedte; waar die het smalste was, werd de helling naar binnen minder steil, zoodat men daar het gemakkelijkst kon afdalen. Nergens was een doorbraak aanwerig, waruit het inwendige kan uitgestroomd zijn ; de grond was met eene dikke laag humus bedekt. Van lava of vulkanische stoffen vonden wij niets; slechts eenige lichte poreuse steenen werden hier en daar gezien, die warschijnlijk tot de formatie van den berg zelf behoorden. Het ongebaande voetpad, dat over den geheelen ring liep, hewees, dat de inlanders hier soms ronddwalen, om bosch-produkten te zoeken; hieronder behooren ook de eieren van den Maleo (Megapodius), wiens kolossale nesten of aardhoopen wij aantroften. Al kostte het veel moeite, door deze wildernis te dringen, vooral waar het pad geheel met allang-illang was dicht gegroeid, en ofschoon wij, er tot over de ooren inwadende, in de brandende zon een doortocht moesteu vinden, hadden wij niettemin in twee ureu den cirkel afgewandeld en kwamen toen weder bij onze achter gelaten goederen terug.

$\mathrm{Ik}$ vond hier eenige interessante plauten, maar ook vele bekende, zooals kolossale exemplaren van den Canarium commune, wiens vruchten den bodem bedekten; voorts vele vijgsoorten, waaronder mede kolossale boomen; Laurineeën; eene klimmende Strychnos met rijpe vruchten: jonge planten eener suort vau Livistona, wier jonge bladeren tot wateremmers gevormd worden; groote stammen eener Caryota, die voor goten gebruikt worden; verscheiden rotan- en bamboe-soorten; vele soorten van lianen, waaronder een Smilax, die ons met zijne gedoornde, over den grond liggende stengels menigmaal deed strukelen of den weg versperde. Van Scitumineeёn kwamen vele, waaronder zeldzame soorten voor, waarbij ook de Galoba doerian met groote bolvormige vruchttrossen, die niet onaangenaam van smaak zijn; zelfs klapper-en pinang-boomen tooneu nog de plaatsen aan, die hier rroeger bebouwd zijn.

De zuidoostzijde van den berg wordt nog voor een groot gedeelte tot bijna an zijn top bij tusschenpoozen bebouwd en, hoe via free access 
steil ook, toch met padi beplant, nadat al het geboomte, behalve de Arenga saccharifera of aren-boom is weggekapt. 1)ie streek, welke sterk afsteekt bij de aangrenzende bosschen en meer het voorkomen van een boomgaard heeft, bevat honderde en de geheele herg duizende arenboomen van verschillende hoogte en ouderdom, die niet geplant zijn, maar uit door het afstroomende water of door vogels aangevoerd zaad van zelf opgroeiden; toch hebben alle eigenaars, hoewel zij lang niet alle getapt worden. De Alfoeren verstaan de kunst niet, uit dit sap suiker te koken, maar zijn groote liefhebbers van de sagoweer en laten die onmiddelijk verzuren, als ze uit den bloemstengel in de bamboe-kokers vloeit, door steeds wat droesem in die kokers te laten; deze kokers worden derhalve nooit schoongemakt, maar de sagoweer bij de inzameling in daartoe medegebrachte kukers overgegoten. De zuidwestzijde van den berg zoude volgens zeggen minder voor kultuur geschikt zijn, daar het daar te steenachtig is; vandaar dan ook, dat de natuurlijke vegetatie daar nog in volle kracht is. Herten, varkens en koeskoesen moeten hier veel voorkomen; van de zwijneu zagen wij vele sporen in den door hen ongewroeten grond. Witte, roode en groene kakatoes zijn evenals roode loeries hier zeer menigvuldig en maken zich steeds door hun vervelend geschreeuw kenbaar.

Als legende verhaalde men ons, dat de top van den Kerkan van den berg was afgeworpen en in den zelfden vorm er vlak naast was neergezet. $1 \mathrm{Nu}$ staat er werkelijk een kleinere berg naast den Kerkan, die er nagenoeg op passen zou, maar ook deze gaat aan het zelfde euvel mank, dat hij zijn kruin verloren heeft, zoodat die warschijnlijk van b mnen eveneens trechtervormig is. Dit alles bij elkaar voegende en met de vier meren in verband brengende, houd ik het voor waarschijnlijk, dat het een zoowei als het ander aan verzakking van den bodem moet worden toegesehreven.

Den 19den November, des morgens om zeven uur, nam ik de terugreis weder anin en kwam reeds des middags te Tabello, waar ik door den heer Been en zijne echtgenoote vriendelijk

1 Dit is dus weder een geheel andere voksoverlevering, dan de in de noot op bl. 504 hier:oor vermelde legende, volgens welke de koning van Tollo met zijn staf (tarakan) op den bodem sloeg, warop de 900 voet hoog, beig Tarakan of Kerkan eensklaps nit den grond verrees. $\mathrm{R} A$. 
ontvangen en uitgenoodigd werd, een paar dagen bij hen door te brengen, dat ik gaarne aamnam. Des namiddags wandelden wị eerst door de vuile hoofdkampong, daarna zoover mogelijk door de omstreken, en vonden de erven van de hier en daar verspreide Alfoeren veel netter onderhouden, dan die in de hoofdnegorij, en zelfs met eenige soorten van bloemheesters en sierplanten verrijkt, Langs het erf van den heer Been loopt een beekje met vrij goed water, dat echter door veelvuldig geb uik in de kampong te veel verontreinigd is, om het als drinkwater te gebruiken, zoodat de heer Been hier een put liet graven, die heerlijk water oplevert.

De heer Been vergezelde mij den voigenden dag in een prauw naar twee der voor Tabel!o liggende eilandjes, watr eenige menschen uit dit distrikt tijulelijk wonen, om er op den vruchtbaren bodem, meest verweerde koraal-kalk en humus, een weinig landbouw te drijven. Zij telen daar voornamelijk padi, suikerriet en kiadi en evenals de Alfoeren op den vasten wal enkele planten tot sieraad en huiselijk gebruik, die bij sommigen derelfde ziju, als bij de Battaks op Sumatra, zooals de Gomphrena globosa, Ceiosia cristata, varietas plumosa, en wel in vier verschillende kleuren: oranje, geel, donkeren lichtrood, de Celosia argentea, Vinca rosea, Codiaeum Moluccanum, Calodracon Jacquinii en de Hibiscus rosa Sinensis. De Anona muricata of zuurzak was hier reeds verwilderd; een vreemde soort van Broussonetia, waarvan de vrouwen korte baadjes en de mannen tjidako's bereiden, en een fraaie bontbladerige Acalypha behoorden ook tot humne aanplantingen. Deze lieden waren zoo beleefd, dat zij ons zelfs met suikerriet wilden overladen en van de eene hut naar de andere volgden. lk verzamelde langs de stranden nog eenige planten. totdat een regenbui uit de verte opkwam, waarop wij haastig huiswarts kcerden.

Des namiddags ten vijf uur nam ik ten tweedenmale een hartelijk af-cheid van deze warlijk niet benijdenswaardige wegbereiders van het Christelijk geloof, dat dan ook hun eenigste illusie uitmaakt. I hoopte den volgenden morgen reeds te Kauw te zijn, doch de roeiers hadden er anders over beschikt, daar zij zich om negen uur ter ruste legden en de prauw lieten drijven; eerst tegen vijf uur van den volgenden morgen waren zij weer aan de riemen, zoodat wij niet voor half vier des namiddags te hauw aankwanen. Wij hadden toch dien 
gauschen dag tegenwind, zoodat er steeds moest geroeid worden, maar het was aangenaam koel, vergeleken met de vorige dagen; eerst kort bij Kauw kregen wij een gunstigen wind. Om vijf uur werd de reis voortgezet; de zee was toen nog al bewogen met veel deining, doch er kwam wind genoeg opzetten, om wat te kumen zeilen, en met medehulp der riemen kwamen wij reeds des nachts te Babane.

Dikwijls heb ik mị verwonderd, hoe het mogelijk is, dat de roeiers die beweging zoo lang kumnen volhouden, doch mij ook dikwijls geërgerd over velen, die zich op alle mogelijke manieren aan dit werk zoeken te onttrekken, om te eten, te drinken, vuur te maken, te rooken en nog andere, soms zeer noodzakelijke verrichtingen te volbrengen. Jongens van 16 a 18 jaar waren gewoonlijk de beste en meest volhardende roeiers. Gewoonte en oefening schijnt hun dit werk gemakkelịk te maken; benijdenswaardig vind ik het echter niet en toch verkiezen velen het boven veldarbeid of ander geregeld werk.

Den 28sten November, des morgens ten zes uur, landden wị te Babane, wandelden den pas over en kwamen om zeven uur te Dodinga. Met het overbrengen van mijne bagage, maar voornamelijk van al, wat de roeiers op reis hadden ingekocht, zooals tabak, olie en klappers, werd het half twaalf, eer wij van Dodinga konden vertrekken. De eb had hiertoe ook wel wat bijgedragen, daar de met klappers en andere goederen vol geladen prauw moeielijk uit de rivier te brengen was.

De weg van Dodinga na:r Babane is mijns inziens zeer ondoelmatig angelegd en vormt een groot bezwar voor het vervoer der prauwen, die er overheen gesleept moeten worden. Ik geloof, dat de steile hellingen, die men nu, zoo te Dodinga als te Babaue, heeft, zouden kumen vermeden worden, door te Dodinga niet in eens steil naar boven te gaan, maar den oever der rivier te volgen en, dus laugzamerhand klimmende, het hoogste punt, dat men op den pas moet passeeren, te bereiken. Van daar zou men weder door eene vallei geleidelijk kumuen afdalen tot vlak voor Babane, waar die vallei door een hoogen dam gesloten is: dezen dam zoude men kumnen uitgraven, of wel er een tunnel doorheen moeten leggen, zoodat men bijna gelijkvloers te Babane aan strand zou uitkomen. Ik geef dit echter slechts voor beter; een nader nauwkeurig onderzoek ter plaatse, waartoe ik niet geroepen en ook niet in de gelegenheid was, zoude moeten uitmaken, in hoever dit plan uitvoerbaar is. ke Volgr. 1 . 
Wel weet ik, dat er vroeger gelden tot verlegering van dien weg zijn toegestaan, doch dat die verbetering niet heeft plaats gehad. Ook is de bevolking van Dodinga te gering en met te veel werkzanmheden overladen, om dit werk ten uitvoer te kumen brengen: men zoude daartoe echter eenige der meestal niets doende kettinggangers kumnen bezigen.

Eindelijk geraakien wij met roeien en duwen buiten de rivier en hadden aanvankelijk goed weer en een weinig wind, om te zeiten. T'egen drie uur des namidlags kregen wij echter zoo zware deining. dat de prauw geweldig begon te slingeren en de vlengeis met geweld in het water ploften. Ik begon zelfs te vreezen, dat ons vaartuig er onder bezwijken zou; dat dit niet onmogelijk was, hebben toch vele voorbeelden geleerd, want er behoeft slechts een der niet zeer hechte vlengels te breken of los te raken, om het vartuig te doen zinken. Ik hield de roeiers in het oog, om te zien, of zij er ook gevaar in zagen, doch op hun gelaat was geen vrees te lezen. Dit boememde mij dan ook weder nieuwen moed in, maar toch was ik niet recht op mijn gemak, daar de golven telkens over den rand der prauw heensionegen en dit vaartuig zoo lek was, dat er gedurig moest gehoosd worden. Die onaangename toestand hield aan, totdat wij on zeven uur des avonds onder den wal van Ternate kwamen, waar de zee wat kalmer was, en wij voor den kraton van den Sultan van Tidor 1 den vasten wal bereikten."

1 In dit gebouw neemt de Sultan van Tiłor zijn intrek, wanneer hij zich op Ternate bevindt. Na de reis naar Nieuw-Guinea was het door de Tidoreesche Priısen, die aan den tocht derwarts hadden deelgenomen, tijd lijk aan den heer Teysinann ten gebruike gegeven. R. A. 